\section{The End of the Ottoman Empire and the creation of the Iraqi state beyond Sykes- Picot: Between Imperialism and Revolution}

\author{
El fin del Imperio Otomano y la Creación del Estado \\ Iraquí más allá de Sykes-Picot: entre el imperialismo y la \\ revolución
}

\section{O fim do Império Otomano e a criação do estado iraquiano para além de Sykes-Picot: Entre o Imperialismo e Revolução}

Reginaldo Mattar Nasser ${ }^{1}$

Rodrigo Augusto Duarte Amaral²

DOI: 10.5752/P.2317-773X.2020v8.n4.p35

Received in: September 06, 2020

Accepted in: October 19, 2020

\begin{abstract}
The consensus in academic literature on the creation of modern states in the Middle East is that the starting point for understanding this process occurs with the Ottoman Empire disintegration and its replacement by European powers. In the case of Iraq, a military campaign and the periods of British occupation (1914-1920) and British mandate (1920-1932) in Mesopotamia paved the way for the creation of the state of Iraq, significantly influencing their later political-historical development. However, in addition to the diplomatic actions established by international agreements and treaties under the guidelines established by the League of Nations, this process did not occur in an empty space, as is often mentioned in that same literature. The clashes over access to the region's oil, exemplified by the dispute over the Mosul region, demonstrate the political-economic character of the construction of new borders. Moreover, this was not only the result of a planned political action by the British Empire, but also resulted from anti-imperialist revolts across the region. In this way, Iraq's final political outcome, and its subsequent development, reflected not only the presence of the imperial powers structures, but also the participation of local communities and groups, in connection with international movements.
\end{abstract}

Keywords: Iraq. Ottoman Empire. British Empire. Mandate System. Oil, Arab Revolts.

\section{RESUMEN}

Hay un consenso en la literatura académica sobre la creación de estados modernos en Oriente Medio en que el punto de partida para comprender este proceso se da en el momento de la desintegración del Imperio Otomano y su sustitución
1. Livre Docente em Relações Internacionais pela PUCSP, Professor da Pontifícia Universidade Católica de São Paulo (PUCSP), São Paulo, Brasil. Orcid: https://orcid.org/0000-0001-5674-4197.

2. Mestre em Relações Internacionais pelo PPGRI San Tiago Dantas, Professor da Pontifícia Universidade Católica de São Paulo, São Paulo, Brasil. Orcid: https://orcid.org/0000-0002-7245-5448. 
por las potencias europeas. En el caso de Irak, la campaña militar y los períodos de ocupación (1914-1920) y el mandato británico (1920-1932) en Mesopotamia allanaron el camino para la creación del estado de Irak, influyendo significativamente en su posterior desarrollo histórico-político.Sin embargo, además de las acciones diplomáticas establecidas por acuerdos y tratados internacionales bajo los lineamientos establecidos por la Liga de Naciones, este proceso no se dio en un espacio vacío como suele mencionarse en esa misma literatura. Los enfrentamientos por el acceso al petróleo de la región, ejemplificados por la disputa por la región de Mosul, demuestran el carácter político-económico de la construcción de nuevas fronteras.Y más, este resultado no fue únicamente el resultado de la acción política planificada por el Imperio Británico, sino que también se derivó de revueltas antiimperialistas en toda la región. De esta manera, el resultado político final de Irak, y su posterior desarrollo, reflejó no solo la presencia de estructuras de poder imperial, sino también la participación de comunidades y grupos locales, en conexión con movimientos internacionales.

Palabras-clave: Irak. Imperio Otomano. Imperio Británico. Sistemas de mandatos. Petróleo. Revueltas Árabes.

\section{RESUMO}

Há um consenso literatura acadêmica sobre a criação dos Estados modernos no Oriente Médio cujo ponto de partida para compreensão desse processo se dá no momento da desintegração do Império Otomano e sua substituição pelas potências europeias. No caso do Iraque, a campanha militar e os períodos de ocupação (1914-1920) e de mandato britânico (1920-1932) na Mesopotâmia prepararam o caminho para a criação do estado do Iraque, influenciando de forma significativa seu desenvolvimento político-histórico posterior. No entanto, para além das ações diplomáticas estabelecidas por acordos e tratados internacionais sob a partir das diretrizes estabelecidas pela Liga das Nações, esse processo não ocorreu num espaço vazio como, frequentemente, é mencionado nessa mesma literatura. Os embates por acessos ao petróleo da região, exemplificado pela disputa da região de Mosul, demonstram o caráter político-econômico da construção das novas fronteiras. Além disso, esse resultado não foi unicamente consequência de uma ação política planejada pelo Império Britânico, mas derivou também das revoltas anti-imperialistas em toda a região. Desta forma, o resultado político no Estado Iraque, e seu desenvolvimento subsequente, refletiu não apenas a presença das estruturas de poder imperiais, mas também devido a participação das comunidades e grupos locais, em conexão com movimentos internacionais.

Palavras-chave: Iraque. Império Otomano. Império Britânico. Sistema de Mandatos. Petróleo.RevoltasÁrabes.

Introduction

There are several similar elements between the British occupation of 1920 in Mesopotamia and the role of the United States (USA) Coalition Provisional Authority (CPA) in Iraq in 2003, both in the type of state to be built and in the fact that state institutions must interact with the population and, above all, which Iraqis should compose the government. Another similarity concerns the role of the USA in both moments. Woodrow Wilson and George W. Bush thought of imposing a new order on the international system periphery and wonderedhow to make structural transformations there, without jeopardizing the interests of the USA and its allies. The USA denies that it had imperial ambitions, because it claims that it does not intended to colonize the Iraqis, but rather to restore its 
sovereignty, leading it to self-government. In his presentation to the United Nations (UN) General Assembly in September 2003, despite speaking of self-determination, President Bush, vehemently opposed any attempt by the UN to transfer power to the Iraqis immediately. Bush used the language of the trusteeship, according to which the USA would be a trustee and the occupation of Iraq had the objective of promoting Iraqis welfare until he could become sovereign.

Early in the First World War, the three Mesopotamian provinces (Mosul, Baghdad and Basra) were the first Ottoman Empire areas to be occupied by British troops and, in 1932, Iraq became the first mandated state to obtain its independence, joining the League of Nations. But Iraq's own experience shows that it's possible for a country to have its sovereignty recognized by the international community and, at the same time, to be tutored by a great power. Under the 1922 treaty between Iraq and the British crown, the basic provisions of the Iraqi Constitution provided, and Britain pledged, to support and assist the armed forces of the King of Iraq when necessary. The King agreed to fully consult Britain on how to manage the country's economy and finances. (DODGE, 2003, pp. X-XIII).

The military campaign and the occupation periods (1914-1920) and British mandate (1920-1932)in Mesopotamia paved the way for the Iraq's State creation, significantly influencing its later political-historical development. However, this process wasn't only a consequence of British political action, but also derived from the Iraqi Revolution in 1920, which made the agreements reflect not only the structures of the imperial, Ottoman and British powers, but also the participation of local communities and groups in determining subsequent developments. One effect of the narrative that consider Iraq as an artificialstate (BARR, 2011) is that it ends up minimizing the impacts on British imperial violence and the actions of anti-imperialist revolts. To imagine that Iraq's borders were created in the rooms of imperial rulers through decrees as if they were acting in a territorial vacuum, a kind of "empty map", is to neglect the dynamics of the struggle between social, revolutionary and counter-revolutionary forces and their claims of rights and autonomy. (PURSLEY, 2015).

The geopolitical disputes and social revolts that spread throughout the Middle East region were concealed in a series of agreements, treated by diplomatic conferences. Thus, we understand that only a closer examination of the historical context allows us to understand what was really at stake. The economic objectives in the British negotiations with France on the Middle East mark another post-war period chapter and referred to Britain's desire to guarantee oil supplies in the future. British Empire negotiators were determined to earn a de jure sanction for their country by the de facto military occupation of Mosul as an integral part of the new Iraqi state. In exchange for giving up what had initially been agreed, under the Sykes-Picot Agreement for Mosul, France should obtain a stake in the oil company to work on the oil concession for the area, once the concession was formally granted by the Turkish Petroleum Company (TPC). (ENGDAHL, 2004, p.42).

Thus, although oil issues appeared marginally in these treaties, we understand that they were inextricably linked to border issues. The 1923 
Lausanne Conference, remembered for the redefinition of Turkish borders in Anatolia, was the space where powers debated whether to include Mosul in Iraq, which on the other hand was related to the presence of oil companies in that region. And despite diplomatic representatives' omissions or denials on the importance of oil matter at the conference, it was a crucial one. In a correspondence between the British Admiralty and its Foreign Office, written days before the opening of the Lausanne Conference, this theme appears clearly giving us the key to understanding British politics in the region: "from a strategic point of view the essential point is that Great Britain should control the territories on which the oilfields are situated”. (BRITISH ADMIRALTY apud SLUGLETT, 2007, p.72).

Albeit, another variable was relevant to the decision-making process of Middle Eastlines: the interference, resistance and interest of different local social groups. From the British imperial perspective on the eastern front of the First World War, a paradox appears. The British did their utmost to preserve and even increase their power in the region, while giving guarantees of access to land and independence to the Arab leaders of the 1916 revolution in exchange for support to fight the Ottomans.Therefore, if, on the one hand, the powers devised seemingly blatant imperialist schemes to divide the land between the British and French authorities, on the other hand they had to deal with the local interests that were already manifesting in that space. Much of the literature on political change, "development" or "modernization", understands the state's image as an active agent interfering in native communities without any resistance, as if they were asleep. This is a distorted image, since the communities of Mesopotamian peoples, the tribal chiefs, were equally concerned with penetrating the state and converting their tribal power into state power (POOL, 1980, p.340).

Another important parallel process, that in a way influenced British behavior in the Middle East, came with the consequence of the Bolshevik revolution in Russia. The threat that appeared for the British with the Bolshevik revolution was less about the Soviet maneuverability south of its territory, and more about the influence of Communist ideology as a possible engine of revolutionary movements in the region.

Therefore, this article aims to develop an analysis of the Iraqi state creation process based on the disintegration of the Ottoman empire and the direct British involvement in its constitution, looking not only at formal, diplomatic and international law aspects, but also at other evident social dynamics. Here we highlight fundamental themes that made up this process, namely: the importance of the oil issue in the territorial definitions and British post-Ottoman control; the role of the social actors in the Arab revolts, partly resisting this process, partly associating with this process; the dispute over Mosul as a key territory for the consecration of British power and access to one of the region's oil sources; and finally the role of another internationalist project that came with the Russian Revolution of 1917 already as an alternative to the liberal international model represented by the North Atlantic powers. It is thought that it is essential to understand the dynamics of these actors (agency), for a clear comprehension of the precepts established in the Treaties and Formal 
Agreements that have consolidated themselves as the main aspect in the literature on the topic of Ottoman disintegration. Such Treaties and Agreements are means and not ends of this process, after all, it is based on the understanding that the International law is an international policy instrument. Therefore, a set of rules, discourses and techniques that its subjects and actors use to regulate their relations and accomplish certain social ends. (JOUANNET, 2014).

In this case, the British mobilizations of power with the "winning" powers of the First War of the time (France and the USA), also with the defeated ones (Turkey and Germany), as well as with local actors, compose this macro process of creation of what we today call of Iraq.

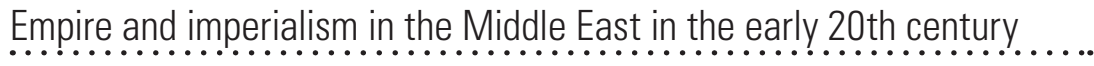

At the beginning of the 20th century, basic rules were established, within the imperialist framework, for the subsequent economic, social and political development of the Middle East. These processes did not operate in a vacuum and when they intruded on the social, economic and cultural life of the region, the transformations were radical. New social classes were created, while others were destroyed. The urban centers were destroyed and rebuilt within the new imperialist parameters. The introduction of new agricultural methods, property rights and markets has rapidly transformed rural life. The imperial dispute between British and Ottomans isolated urban areas from their traditional agricultural hinterlands. The scenario was one of crisis and social discontent. The increase in prices interacted with the growing scarcity and were aggravated by the effects of the economic blockade by the belligerent armies on both sides, resulting from poor harvests and crop failures between 1913 and 1918. The province of Mosul, for example, were in a state of public calamity in November 1918, when thousands of inhabitants died of starvation. (ULRICHSEN, 2014).

The emergence of new classes and the experimentation of new forms of political expression gave a new color to social struggles. This process of expansion of empire spreading the modern economic system in the Middle East meant that investors, landowners and traders started to orient production to the international market. All these economic transformations with significant social impacts could not have occurred without a concomitant political process that suited the expansion of the world economy. (GELVIN, 2011)

The expansion of European empires meant that the entire globe was inserted into the European system of international law by the First World's War end. Thus, at the same time the liberal internationalist proposal, led by the USA, was to dismantle existing empires and facilitate the transformation of their territories into sovereign and independent states, another change was taking place: the emergence of a new international administration system under the auspices of the League of Nations. Until the beginning of the 20th century, sovereign states were the only actors recognized by international law, but with the creation of the League, international institutions emerged as a new actor providing international 
law with a new range of ambitions and strategies for the conduct of International relations. (ANGHIE, 2004, p. 114-115).

Initially, the main challenge for the League of Nations was to take responsibility for dealing with the inherited colonial structure. After months of negotiations and some reluctance, the political leaders of the Western powers ended up accepting the US proposal to create the mandate system, which proved to be a compromise between those who proposed colonial expansion and those who advocated for genuine independence. The annexation of the German and Ottoman colonial territories, the empires vanquished in Africa, Asia and the Middle East, was simply not viable, but neither was providing autonomy to these peoples. In order to get out of this imbroglio, the formula guardianship (or trusteeship) was adopted. That is, although states continue to be the main actors in the Mandate System, the principle of sovereignty has taken on a very different character than existed until then. International institutions, instead of being products of sovereign states, were given the task of creating sovereignty in territories where their inhabitants were considered incapable of exercising the principle of self-determination of peoples. It was in the Mandate System that law and international institutions were able to carry out experiments and develop techniques that would hardly be possible in the sovereign western world (ANGHIE, 2004, p. 133 - 135).

While in the 19th century the division between Europe and "uncivilized" non-Europe was formulated mainly through the elaboration of racial and cultural categories, the League of Nations characterized the differences between the civilized and the "non-civilized" in economic terms: the "advanced" versus the "outdated". According to the League's patronizing (and evolutionary) language, spelled out in Article 22 of the League of Nations Convention established by the Versailles Treaty, mandates should be implemented in territories "inhabited by peoples not yet able to stand by themselves under the strenuous conditions of the modem world” (TREATY OF VERSAILLES, 1919, article 22, p.56). They referred to the European powers that would be in this "stage", capable of helping them to prepare for self-government. It was understood that:

\footnotetext{
"Certain communities formerly belonging to the Turkish Empire have reached a stage of development where their existence as independent nations can be provisionally recognized subject to the rendering of administrative advice and assistance by a Mandatory until such time as they are able to stand alone." (TREATY OF VERSAILLES, 1919, article 22, p.56).
}

The creators of the League tried to cover up that the mandates could be another way of securing their strategic interests in the Middle East, while apparently disregarding the principle of peoples' self-determination. Thus, when the Mandate System was implemented, this artifice was immediately denounced by means of a series of revolts in various parts of the British and French empires (ANGHIE, 2008; PEDERSEN, 2006).

The region corresponding to the Middle East, at that time, was configured as a fundamental space for the British empire repositioning, a vital link in its communications with the East connecting Cairo, Baghdad, to India, Singapore, Australia and New Zealand. However, at that time, there was no consensus among members of the British government as to the extent to which Britain should seek to take over the spoils of the 
Ottoman empire. Some claimed that new annexations could burden the imperial administration, which was going through difficult times due to the costs of war. However, as the war progressed, that point of view lost ground to those who felt that it was necessary to control as much territory as possible in order to maximize Britain's position in the final peace agreement, vis-à-vis the defeated enemy and his wartime allies, who also wanted the spoils' share. (CROZIER, 1979).

Gradually, the territories in the Middle East began to be defined, even before war's end. A series of secret agreements and commitments made by the British Empire during the First World War with the Arabs (Eg: McMahon-Huseyn correspondences of 1915-16), Jews (Eg: Balfour Declaration of 1917) or with their European allies (Eg: 1915 Constantinople Agreement, 1916 Sykes-Picot Agreement). Great Britain adopted the assumption that the end of the Ottoman empire would leave a "power vacuum" in this key area (KENT, 1996, p.165-198).

After 1918, Britain faced a series of problems due to the various war agreements, most of the times, contradictory and/or ambiguous. Several promises were made. Sometimes to different Arab leaders regarding a future Arab state, although they did not specify how far British support would go, what their territorial limits would be, or the degree to which it would be truly independent. Other times to France, where British made concessions to reinforce their fighting spirit in Europe. Clearly, the promises of independent states in Syria and Mesopotamia had the sole purpose of encouraging the Arabs to fight alongside the British. For reasons of security, economic interests, and maintenance of imperial communications, and mainly oil, Britain felt that it had no choice but to occupy the area before another power did it in its place. (KENT, 1976).

When the war ended, Britain found itself at the forefront of the Middle East simply because it was alone in the military occupation of the region with an army, mostly coming from various regions of the Empire. Presenting it as a justification for its claims, Britain argued that it had paid the highest costs of war there and, therefore, should be granted with the greatest gains. (DAVIS, 2010). Britain's military strategy during the war allowed it to have considerable political advantages in negotiations with other victorious powers after the defeat of the Ottoman Empire. The British launched massive attacks from India and Egypt, involving around a million combatants, which allowed British troops to occupy Mesopotamia and parts of the Levant quickly. At the same time, the Bolshevik government of Russia renounced the claims made by its predecessor and denounced the imperialist plots of the French and English by disseminating texts of the agreements mediated by Tsarist Russia, as was the case with the Sykes-Picot agreement (SCHAYEGH; ARSAN, 2015).

Another obstacle to the implementation of secret agreements came from the USA in the figure of President Woodrow Wilson, who advocated for the end of secret diplomacy and that, about the independence of the colonies, "the interests of the populations involved must have the same weight as the colonial power" (WILSON apud GELVIN, 2011 p.442-443).

The European powers that won the First World War met at the San Remo Conference in April 1920, within League of Nations frame- 
3. In April 1909, businessman Willian Knox DiArcy was appointed director of the newly founded Anglo-Persian Oil Company, which would later become British Petroleum. (BRITANNICA, 2020a). work and decided to assign the French mandate to Syria and Lebanon; and Mesopotamia and Palestine under the British mandate. Initially, the British and French governments feared that the new League of Nations mandate would put them under strict limits on their management. Diplomat Mark Sykes protested about the new times saying that "imperialism, annexation, military triumph, prestige, burdens of the white man, were purged from the popular political vocabulary" and, as a consequence, the diplomat continued, "Protectorates, spheres of interest or influence, annexations will no longer be able to be part of diplomatic negotiations." Although this vision of radical change did not happen, the mandate system represented, in a way, a rupture with previous forms of imperial sovereignty. (SYKES apud DODGE, 2003, p.13). Economic exploitation and subjugation of local populations came with a new international liberal guise in the early 20th century, which gave European imperialism a new face.

The importance of the Petroleum issue in the foundation of the postOttoman Middle East.

Still little addressed in the academic literature, which is guided almost entirely by European diplomatic conferences, if we examine the historical process involving imperial competition in the Middle East, we will realize that oil played a fundamental role in the construction of the international order. During the First World War, industrial development demanded increasing amounts of oil, which came to supplant coal as an energy source in some military sectors.

Once oil began to be widely used by the world's navies, it was considered essential for the Great Powers that supplies and reserves should be freely available. They made sure to ensure that their own access to sources. Hence the guidelines of British oil policy were formulated very quickly: Britain should be in a position of political influence or control in territories where oil was known, or equally important, thought likely, to exist, and that other powers should be excluded as far as possible, both politically and commercially, from these areas (SLUGLETT, 2007, p. 66). At the end of the First World War, no Great Power was unaware of the strategic importance of the new fuel for future economic and military security. (ENGDAHL, 2004, p38-39).

In this context, the war policy was revised, shifting the focus to the eastern front, where Britain was expected to achieve some victories by offsetting Germany's conquests in Europe. It wasn't believed that peace could be achieved before 1919. When the armistice took place in November 1918, decisions had already been taken in relation to the Middle East, which would have profound historical consequences in the future. (MILLMAN, 2014). Actually, before the beginning of the war, Sir Edward Gray, British Secretary of State for Foreign Affairs, sent ultimatums to the Ottoman government, protesting its plans to create an oil company in the vilayets of Mosul, Baghdad and Basra, arguing that any company created in the vilayets needed to offer the D'Arcy group ${ }^{3}$ at least a 50\% stake in its operations. On March 19, 1914, an agreement was signed that merged the interests of the TPC and the D'Arcy group, the new group 
asked the Ottoman government to grant oil in the vilayets of Baghdad and Mosul, but the outbreak of the war prevented a final agreement (MEJCHER, 1972, p.377).

Regarding the British government's interests in Middle Eastern oil in the years before the war, two facts deserve to be highlighted. First, the Ministry of Foreign Affairs wasn't prepared to accept for Mesopotamia any company that would give the D'Arcy group less than $50 \%$ of the shares. Second, on May 20, 1914, the British government signed an agreement with the Anglo-Persian Petroleum Company (APOC), which gave it a majority stake and vote in the decisions of the oil companies involved. The government's purchase of shares set a precedent for possible government involvement in Iraq's oil regions. (MEJCHER, 1972, p.378).

The combination of British national interests and changing priorities during the war, with strategic situations on the Eastern Front, the Middle East and the Caucasus, significantly influenced the objectives of the British Empire, as well as its insertion in these regions. The importance of oil, in 1918, became the crux of British politics throughout the Middle East and the Caucasus, configuring what some called "oil imperialism”. (SLADE; FISCHER; MOHR, 1928).

Despite the signing of the Mudros Armistice, on October 30, 1918, which ended conflicts between the Ottoman Empire and the Allies in the Middle East, Lieutenant-General William Marshall occupied Mosul on November 2 of the same year, to guarantee Britain to retain oil for the "right of conquest". (KENT, 1976; ENGDAHL, 2004). Almost immediately after the end of the Sykes-Picot Agreement, the War Committee returned to discuss the interests of the British Empire in the Middle East. At a committee meeting on July 6, 1916, Mark Sykes signaled the strategic relevance of the region for Great Britain, emphasizing the great value of "immense oil areas". According to him, although the Flanders camps could decide the battle, Germany was also fighting for the Middle East. Sir Arthur Hirtzel, senior British officer in India, agreed with Sykes' opinion, expressing his assessment in two memos on the subject, dated May 25 and October 31, 1916. (KENT, 1976, p.124-125).

The Foreign Office memorandum of March 1918 had noted that this was a matter which cannot be treated as a purely commercial venture but must be envisaged as a national responsibility, which admits of no half-measures or ill-considered action. At a conference at the India Office later in the year, Colonel A. T. Wilson explained that: "oil is the only immediately available asset of the Occupied Territories, the only real security the Iraq administration are in a position to offer for the loan which they will undoubtedly require in the near future from the British Treasury". (WILSON apud SLUGLETT, 2007, p. 69).

Historical reports often recall the sudden advance on Mosul in 1918 and the bold capture of the city shortly after the negotiation of the Turkish armistice, but the reasons that led to this are not properly addressed. Strategically, the capture of Mosul had been a fundamental tactical move within the range of alternatives in British great strategy which still sought to establish connections with Armenia and southern Russia. Furthermore, Mosul had been the gateway to the Turkish-German forces that threat- 
ened Baghdad and its closure was a desirable goal for British commanders in Mesopotamia. Mosul's takeover seemed to fit well for the blow to Syria, the mountain ranges north of Mosul appeared as a safe northern border to the open plains of Iraq; but in August 1918, when the time came for action, there was no plan for a united Iraq. Mosul still belonged to the sphere attributed to the French by the Sykes-Picot Agreement. (MEJCHER, 1972).

Although this agreement was considered obsolete by experts like Mark Sykes, the French government, insisted on its validity. On the other hand, Lloyd George had already affirmed to his cabinet that, in the case of Syria, he would use the right of conquest to reopen the whole question of the bargain made with France. Militarily, for Mosul, there was a pause in front of Marshall's forces in the summer of 1918. The Mesopotamian campaign had ended in a dead end on the northern borders of Baghdad vilayet. However, Lloyd George's plans for how to make use of the British occupation of Syria offered space for interested British pressure groups and the Admiralty in adjacent Iraq. At the end of July and during the following weeks, when there was no military advantage in advancing in Mesopotamia, it was the oil interests and the concern of the Admiralty about the future oil situation in the Empire that put the most severe pressure on the Cabinet. (MEJCHER, 1972, 382-383).

In April 1919, even before the signing of the Treaty of Versailles, a provisional oil agreement had been signed by the British and French oil ministers, Long and Bérenger. Before that, the French handed over Mosul to Britain in December 1918, receiving nothing in return. Therefore, the Long-Bérenger agreement was a reckoning of this situation, solving the problem by making over Deutsche Bank's former $25 \%$ share in the TPC (confiscated during the war by the Custodian of Enemy Property) to French interests. Later, it was formalized in the San Remo Agreement, as we'llsee (KENT, 1976, p.140).

In this context, US government strongly opposed themselves to the San Remo Agreement that stablished that companies that would work in the Iraqi oil fields should be under British permanent control. According to the State Department a clear violation of the Open-Door liberal principle, for the protection of equal privileges among countries trading. In addition, it contested the TPC claims, questioning the validity of the original concession. However, the British government feared that continued American opposition was likely to jeopardize the whole future development of Iraqi oil. So, they agreed for the accommodation of the USA interests, to the extent of approximately a quarter of the Company's capital share, later in 1923. This marks an alliance relationship between the British and the North American in the division of portions of the development of the oil markets in the region. (SLUGLETT, 2007, p.70).

In 1920, the British empire oil policy evolution had become closely associated with oil companies in Mesopotamia, recognizing the need to control oil sources and suppliers both in the areas of the Empire and in their areas of influence, such as Persia and Mesopotamia, as well as in areas explored by companies under their control such as APOC and the Royal Dutch-Shell group. Although Mesopotamia always appeared as an important strategic area for the British Empire, because of the Persian 
Gulf and India, the war brought an entirely new situation. The British Empire was confronted not only with military commitments - which, at the end of the war, provided an administration whose main objective was to occupy enemy territories, followed later by an administration of the mandate - in addition to competing with its allies for control over areas of the Ottoman Empire. (KENT, 1976 p. 156). In that context, the British empire was both facing a diplomatic dispute against other great powers, mostly USA and France, meanwhile trying to control the surging uprising in Baghdad result of the remnants of interest of the 1916 revolting Arabs, who fought the Ottoman Empire with British support in the context of the First World War (SLUGLETT, 2007).

During the first half of the war, when economic reasons still did not play a relevant role in its interest in the region, London allowed the French to enter Mosul. After that, however, among his political concerns about Mesopotamia, it was hoped to restore Mosul to his own sphere of influence. His political relations with France began to turn to that end in several attempts at settlement in the immediate post-war years. In April 1920 - as part of the San Remo Agreement - in exchange for regaining Mosul, Great Britain agreed to grant France a stake in its oil, which depended, however, on negotiations with the Royal Dutch-Shell group, as established in the Long-Berénger Agreement, which would later be revised. As a result of this agreement, the French Compagnie Française de Petroles (CFP) acquired a 25\% share in the TPC. The other shareholders were the APOC with 47.5\%, the Anglo-Saxon Petroleum Company 22.5\% and the remaining 5\% Calouste Gulbenkian. British control was recognition of the legality of its title for Mesopotamian oil. Although this agreement was also ready in draft, in April 1920, it never reached the Cabinet for ratification, and was overtaken by events that required modification of the Anglo-French agreement (KENT, 1976, p.140).

The 1920 agreements show how closely the Mesopotamian issue has intertwined with energy policy. In 1920, Mesopotamian oil, still commercially hypothetical, came to occupy an important place in British diplomatic and military concerns in the Middle East. At the end of the First World War, concerns on oil shortages became central to international politics. After the war, the change in the international scenario - with the eclipse of Germany, the breakup of the Ottoman Empire and the conquest of a strong bargaining position on the part of the winners, Great Britain and France - made the problem even more complicated, and the Mesopotamia with its oil potential has become an important key problem in resolving Anglo-French relations. Britain's main concern was essentially the need to secure oil for its Navy. (KENT, 1976, p.157).

After the end of the First World War, the main imperial rivals of the British in the great Middle East (Germany, Ottoman Empire and Russia) collapsed, thus eliminating concern for the defense of India. The APOC had consolidated its operations in Khuzestan where it was planning major expansions, relying on the protection of British troops in Mesopotamia, as well as its alliances with local leaders. At the global level, the British diplomatic machine was being led, for the first time, by a group of politicians specialized in the so-called "Eastern Question" and in the new- 
4. Served as Viceroy of India from 1899 to 1905 , during the First World War served in the War Cabinet of Prime Minister David Lloyd George as Leader of the House of Lords, as well as the War Policy Committee. Between 1919-24 he served as Secretary of State for Foreign Affairs. (MOSLEY, 2021). ly created "Middle East" region. Lord George Curzon", one of the most important politicians at the helm of the Foreign Office, has also become known as the leading expert on the "Persian Question". A long-cherished dream of securing Western approaches to India as well as ensuring the continued monopoly of British control over Iran's oil resources and the Persian Gulf area. (EHSANI, 2014, p.55-56).

In the early 1920s, the three pillars of British imperial power were: control of world sea routes, control of world banking and finance, and control of strategic raw materials for energy purpose, namely petroleum. But the British Empire was not alone, a new threat from a former colony, the USA, was rising within the internationalized capitalist economic structure. (ENGDAHL, 2004, p.50).

However, in 1921, after the Cairo Conference and the appointment of Faysal Ibn Huseyn as King of Iraq, the pattern of British general strategy followed in the coming years is discernible. Control of areas where oil was strongly suspected should be invested in Britain through the agency's mandate. If other powers tried to get their nationals to participate, Britain would be prepared to renounce part of the TPC's interest in order to maintain its political position. Until the status of the disputed territories was finally decided, no oil prospecting or research would be allowed. Finally, any concession would have to be ratified by the Iraqi cabinet and parliament. In a political structure built with the support of the British, by a political elite recognized by the British mandate as legitimate. In this scenario, it is clear why British interests would tend to be favored. But an issue was still sensitive. The Mosul question. (AMERICAN PEACE SOCIETY, 1925)

The Mosul oil, Iraq's northern border special location and the financial problems and difficulties of the Iraqi government, formed the main concerns of Anglo-Iraqi relations during the two years following the ratification of the treaty by the Constituent Assembly in June 1924. The exploitation of Iraqi oil by any or all of the allied powers demanded that Mosul remain part of Iraq and ensure that Iraq would be able to defend its territory, avoiding as little as possible the scarce financial and strategic resources of the Iraqi government, again emphasizing its strong British dependence (SLUGLETT, 2007, p.65).

Therefore, the Mosul question was rightly predicted to be the most intractable of all the problems of the peace agreement in Turkey, and the matter was postponed to the later sessions of the Lausanne Conference in 1923. Notorious international policy analyst Harold Nicolson at the time highlighted Lord Curzon's rhetorical and diplomatic ability to undermine the Turkish case, but he underscores the great delicacy of the situation, especially in view of the British fear of provoking another crisis with Turkey. (SLUGLETT, 2007, p.71-72).

The territorial issue of Mosul was finally established in July 1926 with the establishment of the tripartite agreement between Turkey, Iraq and England (TRIPP, 2007, p.59). So, what is proved is that the events between the ratification of the treaty and the final ratification of the Mosul boundary served to emphasize Iraq's continuing subordination to Britain. Therefore, it became evident that there were no alternatives that could resist the British resolutions for the Middle East territories by the middle of the 1920s. 
After that, the mandate formed a period of general cooperation with Britain, in contrast to the sharp conflicts of the earlier years. Consequently, the two governments started to lose the formal ties bind them, and Britain began to relax its direct control of Iraq. (SLUGLETT, 2007, p.91).

Arab revolts and the participation of local actors in the process of Ottoman disintegration and creation of Iraq

The name attributed to the Sykes-Picot agreement came after the two diplomats Sir Mark Sykes, from the British war office and François Georges-Picot, French consul in Beirut, participated in secret negotiations carried out between 1915 and 1916 in which the former provinces of the Ottoman Empire would be by the British and French in zones of control. Although there is a surprising consensus among journalists and historians who see Sykes-Picot as one of the causes of artificial borders in the Middle East, the agreement was already obsolete at the end of the First World War (PURSLEY, 2015). However, regardless of the facts, Sykes-Picot has become one of the most representative symbols of Western treachery and conspiracy to usurp the sovereignty of the peoples of the region in the region. (RENTON, 2016). This idea of anti-imperialist resistance in the Middle East began to take shape in the context of Ottoman disintegration in at least two moments: in the struggle for independence against the Ottoman empire and, subsequently, against the European presence in the region. Understanding how this historical process took place is fundamental to comprehend the formation of Middle East states.

The role of the Arab rebels in the Middle East against the Ottomans was crucial to the victory of western Europeans on the eastern front of the First War. It is estimated that more than 50,000 Arabs died in battle between 1916-18 against the Ottomans. In fact, an ideological battle was evident at the beginning of the First War, in which the Ottomans tried to appeal to an Islamic solidarity that was supposed to protect itself against Western invaders. In November 1914 the sultan-caliph issued a call to jihad, urging Muslims the world over to unite behind the Ottoman Empire in its confrontation with the Triple Entente. It portrayed the Entente powers as states bent on destroying Muslim sovereignty around the globe and warned Muslims that unless they responded to the jihad, Islam faced extinction. However, the tactic proved to be ineffective. There were many who did not agree that the Ottoman Empire would be the legitimate "Islam protector". (CLEVELAND; BUNTON, 2009, p.153).

In 1915, for example, Jamal Pasha, one of the representatives of the triumvirate who led the Ottoman government, imposed drastic measures in the Arab territories under his leadership. He imprisoned notable Arabs on suspicion of disloyalty and sent them to military courts to be questioned and tried. Many were hanged in a public square, which was a shock to Arab society at the time. (CLEVELAND; BUNTON, 2009, p.154). The problem was aggravated when the British managed to articulate themselves with this unsatisfied portion of society under Ottoman power. Between July 1915 and March 1916, Mecca emir Sharif Huseyn Ibn Ali - who proclaimed the 1916 Uprising - communicated with the British high commissioner in 
5. The Hashemites were represented by three main individuals, Sharif Ibn Huseyn leader of the 1916 Arab Uprising, and his sons Faysal and Abdulah, both respectively kings of Iraq and Transjordan (now Jordan) after the Cairo conference in 1921, representing the link that materialized British interests in the territories under the mandate system. (BRITANNICA, 2020b)

6. The loss of the kingdom of Hejaz took place in dispute with the Saud family, which started a military campaign against the Hashemites in 1924, whose administrative effort at that time was mostly focused on Iraq and Transjordan in the Mandates context.(CLEVELAND; BUNTON, 2009, p. 232)
Egypt, Sir Henry McMahon, establishing the conditions for the British-Ar$\mathrm{ab}$ alliance against the Ottomans. It meant that the British were informally agreeing on the possibility of recognition of an independent Arab state, which had never been formalized along the lines thought by the Arabs led by Huseyn. The Arab revolt path to Damascus followed from Hijaz (Red Sea coast in present-day Saudi Arabia) through the port city of Aqaba (captured in 1917) and then on the right flank of British general Allenby in the final offensive of 1918. The military forces of Sharif Huseyn were commanded by his son, Amir Faysal, who was assisted by a group of former Iraqi Ottoman officers and a small contingent of British military advisers, including Captain T. E. Lawrence (FROMKIN, 2009. p.156-157).

The military and autonomous ability of the Hashemites ${ }^{5}$ caught the attention of the British. However, Sharif Huseyn's support base was not built circumstantially. His conditions were established even before the context of the First War from his notorious position as Sharif (supervisor, leader) in the Mecca region who, despite recognizing that he had been under the Ottoman empire since 1500, maintained a great degree of local autonomy, including with an own army capable of sustaining not only the independence of the Kingdom of Hejaz for almost ten years (1917-1926), but also serving as a local base for the establishment of Iraq and Transjordan (present-day Jordan) (CLEVELAND; BUNTON, 2009, p. 157-161).

The term "Sharifian" refers to those individuals who were associated with the Sharif of Meccass revolt in the Hijaz against Ottoman Imperial rule and to those who were involved in the temporary administrations in Syria and Jordan between the end of Ottoman rule and the beginnings of the Mandate System. Most "Sharifians" were officers in the Ottoman armies and had, in the confusion of war and military defeat, found their way to Hijaz and Syria at different times and by many assorted paths. Most of them came from lower social backgrounds. In the Ottoman Empire, only some urban cities had infrastructure for military education and insertion of people in the military. Baghdad housed one of the few military preparatory schools in the Arab provinces of the Ottoman Empire, and most of the Sharifian officers had their introduction to military life through their attendance at this school, which provided the opportunity for social and political advancement unavailable to Ottoman Arabs elsewhere in the Empire. In many ways, these Sharifians were the core of the movement for Arab independence and a major political beneficiary of that struggle in past-Ottoman Iraq. They were the material and military basis for Hashemite success (POOL, 1980, p. 332-340).

Later, on the foundation of the new Iraq, the great majority of the Sharifians depended on the new state, as they had depended on the Empire, for their daily bread. Unlike the older breed of Ottoman officers, they were not assured of converting their position in the state apparatus into a position in society: the war had intervened, the Empire had been dissolved and they were still quite young. Unlike the tribal leaders that tried to resist European presence in the Mesopotamia region, they had no "natural" followers and no ready-made clientele. In fact, their position resembled that of their leader, the Amir Faysal, in that it was one of total political dependency. (POOL, 1980, p. 332-340). 
It is also important to note that Huseyn's revolting leadership was not unanimous among Arabs. Some Arab public figures accused Huseyn of being a traitor, condemning his actions dividing the Ottoman-Islamic Empire at a time when unity was most needed. The Arab Revolt did not constitute a total uprising against the Ottoman Empire. Rather, it was a more narrowly based enterprise relying on tribal levies from Arabia and dominated by the Hashemite family. There can be no question, however, that Arabs applauded the final triumph of the revolt - the capture of Damascus in 1918 - and that it laid the foundations for the Arabs' claim to an independent state. (CLEVELAND; BUNTON, 2009, p.161). And more than that, this revolutionary inspiration would stimulate other important movements in the region in the following years.

At the time, when Faysal wrote this he had every expectation that he would become king of Syria. Indeed, one year later he was elected King of Syria by the Syrian Congress in March 1920 and his brother Abdallah was elected King of Iraq by a separate meeting of Iraqis shortly after. (POOL, 1980, p. 337) But they soon became kings without reigns, since at the same time France claimed its rights over Syrian territory, as determined by the powers in the League of Nations. As expected, these decisions deeply displeased the Arabs, since when asked to make a choice between Faysal and France, Britain opted for its European ally. (YAVUZ, 2017).

With the Mesopotamia campaign, the British had drawn the Ottoman provinces of Basra and Baghdad into their Persian Gulf sphere of interest. Without staking an explicitly colonial claim to Iraq, Sir Henry asserted that "the established position and interests of Great Britain" necessitated "special administrative arrangements" to secure the provinces of Baghdad and Basra "from foreign aggression, to promote the welfare of the local populations and to safeguard our mutual economic interests" this represented in essence, the integration of Mesopotamia into Britain's trusteeship system in the Persian Gulf within the auspices determined sequentially by the League of Nations in the Mandate System. (ROGAN, 2015, p.381)

The Treaty of Sèvres (August 1920) intended to formalize Ottoman surrender to Great Britain and France, as well as the agreements between Great Britain and France made in San Remo (April 1920), transferring legal titles to the territories to be maintained as League of Nations mandates. (SCHAYEGH, C; ARSAN, A, 2015).

So, without receiving what the British promised, the same rebels that initially tried to install an autonomous political center in Greater Syria between 1918-20 were expelled by the French. The Franco-Syrian war from March to June 1920 demonstrated the strength of an international power over a brave Arab group that overestimated itself. The Arab nationalist bloc in the government urged Faysal to challenge the allied powers, while more cautious voices advised him to seek a compromise that could somehow satisfy French demands and still preserve the Syrian kingdom. Unsure of what advice to follow, Faysal tried to open negotiations with the French commander in Beirut, General Henri Gouraud, but he was unwilling to compromise and ordered his troops to march in Syria. On July 24, 1920, French forces easily defeated Faysal's army, occupied Damascus and forced the king of Syria into exile in Europe. The 
7. To have a dimension of the different historical narratives about the 1920 revolution, it is recommended to read the first chapter of the book "Reclaiming Iraq" by Abbas Kadhim (2012).
8. For a greater dimension of which were these tribes, their leaders and how they connect themselves, it is recommended to read the article by Amal Vinogradov: The 1920 Revoltion Iraq Reconsidered: The role of Tribes in National Politics, 1972. independent Arab state in Greater Syria was eliminated shortly after it was proclaimed (YAVUS, 2017, p.583)

The 1916 Arab Revolt spirit of success against the Ottomans left gaps in power in the peripheral regions of Mesopotamia and the Levant, added to the attempt, albeit unsuccessful, to sustain an independent Arab state in Syria between 1918-20, inspired many the struggle for independence in a scenario of redefinitions and uncertainties in the Middle East. It was at that time that tribal forces not aligned with the Hashemites, rebelled against the British presence in the region off the Tigris and Euphrates rivers between May and October 1920 (MCNABB, 2016).

There are several controversies in historiography regarding the causes and motivations that caused the 1920 revolution in Iraq, as well as opposing reports of personalities involved in this historical process at the time of its occurrence and in retrospect. For a long time, these events were presented in the literature as indisputable facts, but in fact they were part of the narrative presented by the British authorities. Regardless of how it is analyzed ${ }^{7}$, the fact is that the 1920 Revolution was an attempt by Iraqis to obtain their freedom from a violent occupation. Thus, as in other revolutions involving agrarian societies, in Iraq the revolt against abusive taxes introduced by the British administration was the denotator of the movement. The nature of the social and political struggle unleashed, involved various political groups as a complex process involving tactical and strategic changes. The spirit of initial cooperation between Shiites and Sunnis, since the biggest contradiction was a socio-economic dimension, would then be replaced by animosity, with the encouragement of the British who adopted the motto: divide to rule (KADHIM, 2012).

Sometimes called as an insurgency, rebellion and revolt, we chose to call events of resistance the British presence in Iraq in 1920 as a revolution. Mainly because - in addition to other factors in that context, such as the end of the First World War and the approval by the League of Nations of the Mandate System - its effects led to significant changes in the Iraqi political structure. Therefore, we consider the category of political revolutions that, by popular force, transform the structures of the State, but do not necessarily transform the social structures, as do the social revolutions (SKOCPOL, 1979, p.4).The main goal of the revolution: to reclaim Iraq from six and a half centuries of uninterrupted foreign rule (12581920). The population, except for a minority of the affluent, was united against a domineering British occupation that had replaced the equally exploitative four-century Ottoman occupation (KADHIM, 2012, p.4; 7).

AlthoughIraq 1920 Revolution lasted only six months, it was in fact an important parallel movement that took place on the most important cities (Baghdad, Basra, Hilla) margins and was essentially an uprising carried out by tribal forces ${ }^{8}$, but there were also a noncombatant involvement of the urban areas. Intellectuals in Baghdad and other major cities contributed to the ideological framing of the revolution and provided the tribes with valuable awareness and a sense of nationalist direction (KADHIM, 2012, p.6).

If, on the one hand, the main cities like Baghdad, Hilla and Basra were not taken over by the rebels due to the high British occupying mil- 
itary capacity in them, the marginal cities such as Karbala, Najaf, Kufa, Samarra, Fallujah and Diwaniyya, were the space of greatest dispute between occupiers and rebels. There, tribal forces besieged, attacked, and finally captured them after the initial evacuation of the British. And they managed to occupy, but it would be short lived. Later, when the tribes were being subjected to overwhelming British bombardment, these cities were the first to surrender and to accept all the British conditions, while the tribes remained fighting until the end of the revolution. When in the fifth month of revolution the first city was taken over by the British, a domino effect began and in a few weeks the revolutionary forces lost total control of these cities. As soon as the tribes lost the city of \wairijbetween Hilla and Karbala - on 12 October 1920, notables in Karbala, began to form a committee to negotiate a surrender with the British. The city opened its gates a week later. The same happened to Najaf after the capture of Kufa. The British captured Kufa on 17 October 1920, and Najaf surrendered the next day.(KADHIM, 2012, p.6).

Over 6,000 to 10,000 Iraqis were killed, with the loss of around 500 British and Indian troops. Despite the evident British military superiority, it was the huge cost of this operation, over 40 million pounds sterling, which led to a change in British policy. Also, USA pressured the British, because it had a legal obligation to rule Iraq (this is the actual definition of a mandate) but it was a tiresome duty (LLEWELLYN-JONES, 2015, p.276).

While these events did not follow the patterns of "major revolutions" such as the French or Russian Revolutions, that resulted in great political and social transformations. Iraqi 1920 revolution did not have immediate transformation, and as expected, the removal of British presence in Iraq. Even though, it is important to consider the levels of public participation, the social and political networks involved in the events (KADHIM, 2012, p.8). We understand that these resistance movements did result in major changes in the way Britain intended to govern Iraq during mandate system. Also, it encouraged the emergence of a nationalist feeling never seen before in that region. In fact, an Iraqi identity was beginning to exist there.

The 1920 uprising was a political revolution as evidenced by the changes it imposed on the existing political structure, reversing British policy in Iraq. The British claimed that the events of June-October 1920 didn't impact in the process of political construction in Iraq, however it did succeed in "discrediting the India Office policy thoroughly, and it assured a much larger measure of participation by the Iraqis in their first national government" (MARR; AL-MARASHI, 2017, p.19-23), and also promoting Arabs to administrative posts in Iraq (LLEWELLYN-JONES, 2015, p.276).

Even before the first communications with Sharif from Mecca, the British, through British India, invaded Basra in what would today be southern Iraq in 1914, on the eve of the First World War. The action was part of a daring project, Lord Hardinge, the Viceroy of India, pointed out to the Secretary of State for India that the purpose was to "create an immense impression in the Middle East, especially in Persia, Afghanistan and on our frontier, and would counteract the unfortunate impression in the Middle East created by want of success in the Dardanelles" (HARDINGE 
apud, LLEWELLYN-JONES, 2015, p.274). By 1915 the Government of India stated that it expected to annex at least Baghdad and Basra. It was between 1918-20, that such domain was established, in that period Iraq was administered by Sir Arnold Wilson (Iraq's Acting Civil Commissioner), he was an Indian Army Officer and later in Indian Political Department, with considerable experience in the Middle East. In that context, an "Iraq Occupied Territories Code" was created following the model of Indian laws and under the authority of members of the Indian Political Department. (LLEWELLYN-JONES, 2015, p.275). This replaced the old ottoman form of administrations of the region. However, this model proved to be insufficient, and Iraqis realized after six years of heavy-handed military administration that Britain's promises had not been made in good faith.

The model of occupation was largely based on nineteenth-century ideas of the "white man's burden," a predilection for direct rule, and a distrust of local Arabs' capacity for self-government. It was proved inefficient. Therefore, the first attempt of British administration, the imposition of the Indian colonial model, failed after a nationalist revolt in 1920 (MARR; AL-MARASHI, 2017, p.17). Later, on 1 October 1920, Sir Percy Cox landed in Basra to assume his responsibilities as high commissioner in Iraq and implemented the change in British perspective for Iraq. The first decisive step in creating new Iraqi states political institutions and the new British role in it, took place at the Cairo Conference of 1921, and in a way considered the need to give more voice to local actors. It seemed that the pressure of the 1920 revolution had some effect.

With the definition of a monarchical model, on 27 August 1921, Faysal was installed as king. As a monarch imposed on Iraq by an alien, dominant power, Faysal was always conscious of the need to put down roots in Iraq and to appeal to its different ethnic and sectarian communities if the monarchy were to remain. With Faysal's accession, the Iraqi nationalists who had served with him in the war and who had formed the backbone of his short-lived government in Syria returned to Iraq. Staunchly loyal to Faysal, Arab nationalist in outlook, yet willing to work within the limits of the British mandate, these repatriated Iraqis rapidly filled the high offices of state, giving Faysal the support he lacked elsewhere in the country. This handful of young, Ottoman-educated Arab lawyers, officers, and civil servants soon achieved a position in Iraqi politics second only to that of the British and Faysal, displacing the older notables originally installed by the British. This also had the effect of Arabizing the regime, a process intensified by the shift from Turkish to Arabic in the administration and the school system. Strong pan-Arab orientation, it thwarted the development of a more inward-looking. Also, as a result of Cairo's Conference, it established a native Iraqi army (MARR. AL-MARASHI, 2017, p.20-21).

Throughout the decade of Faysal's reign, the structure of the Iraqi state was established. This decade was marked by several agreements between the Iraqi kingdom and the British in order to secure their interests in the country for later. Between 24 October 1922 and 25 February 1924, a Constituent Assembly was established to elect the country’s first parliament, to draft a constitution and to ratify the Anglo-Iraq treaty of 1922, designed to allow for local self-government while giving the British control of foreign 
and military affairs. Thereafter, the form of government was incorporated into the organic law of 1925, in which Iraq was defined as a hereditary constitutional monarchy, with an elected bicameral legislature. Islam was the religion of the state, and Sharia courts, for Sunnis and Shiites, maintained jurisdiction over personal status. Other basic national institutions were quickly created. The Iraqi army, which was to be a national symbol and an essential instrument of state authority, was founded in 1921 and expanded after 1932 independence. (CLEVELAND; BUNTON, 2009, p.207).

Since the establishment of a national government, Iraqis have increased their political participation through the organization of political parties. Three parties formed in 1921, one by the group in power led by the Hashemite family and two by opposition parties seen later as the nationalist alternative in the country, the Watani Party (Patriotic) and the Nahda Party (Awakening) both had the same political objective: terminating the mandate and winning independence, but they differed on the means of realizing it. The Iraqi nationalists were far from satisfied with the parliamentary system established by the mandate. They demanded independence as a matter of right, as promised in war declarations and treaties, rather than as a matter of capacity for self-government as laid down in the mandate. Various attempts were made to redefine Anglo-Iraqi relations, as embodied in the 1926 and 1927 treaties, without fundamentally altering Britain's responsibility. For these Iraqi nationalists, British treaties seemed to be an impediment to the country's true economic development. They argued that there were two governments in Iraq, one foreign and the other national. (TRIPP, 2008, p.52-57)

In July 1927, the British government had promised King Faysal that it would recommend Iraq for admission to the League of Nations. In 1932, Britain's promise of September 1929 was part of a wider policy of retreat from an absolutist form of empire toward a more liberal or informal type of empire. (SILVERFARB, 1982, p.11-22) By the beginning of 1930 it was established another Anglo-Iraqi Treaty that would consummate Iraqi path to independence: it relinquished the mandate and withdrew its ground troops but retained airbases in Iraq. The British government had withdrawn all British and Indian ground troops from Iraq, but it still maintained squadrons of military Aircraft, stationed at Mosul, Hinaidi (five miles from Baghdad), and Shaiba (ten miles from Basra), plus a seaplane anchorage at Basra, after independence. (SILVERFARB, 1982, p.23; 31).

It was in the thirteenth annual assembly of the League of Nations, on October 3, 1932, that was voted unanimously to admit the Kingdom of Iraq to membership. Iraq was the first and only mandated territory to shed its tutelary status and be granted independence through collective agreement. However, British never really went out of Iraq, whether formally through the 1930 treaty, or informally through the close relationship with the Iraqi Hashemite elite (TRIPP, 2008, p.73).

This process therefore reveals that the British appointment of Faysal was both a modification of the original Iraqi plan for independence, due to pressure from Iraqi society, but also a move to secure British interests by installing a government more friendly to the empire than the one established by the revolution leaders of previous year. 
Confrontation between different internationalisms

Initially, the Peace Conference in Paris appeared as an unprecedented historic moment for colonized, marginalized and stateless peoples around the world to achieve self-determination. With the strengthening of international institutions, the subjugated peoples believed they could take the fight against imperialism, through their representatives, to the international arena and imagined President Wilson as an icon of their aspirations (MANELA,2007). But there were two antagonistic worlds in that world order that began to structure itself in 1919. One was represented in Paris, revealed in the treaties, agreements and the various diplomatic negotiations that multiplied around the world. The other reality was in everyday common actions, where people faced all sorts of social and economic problems. Furthermore, diplomatic actions by peacemakers took place in the shadow of real massacres in repressions against anti-colonial rebellions in Sierra Leone, Saigon, Congo, Egypt, Iraq, Syria, Kenya and South Africa. From then on, the imperial powers, with the intention of maintaining their dominions, began to face social and political movements, whose demands for greater participation and demands for independence expanded rapidly around the world as a result of promises not kept by the imperial powers. It can be said that anti-colonial nationalism is emerging at this moment as a major force in world affairs. (GROVOGUI, 1996).

Three years after the 1917 Russian revolution, the defeat of the German Revolution and the retreat of revolutionary forces across Europe put an end to the projected dream of an imminent world revolution, which made it imperative that the Komintern began to pay special attention to the movements of national liberation in colonial countries. Concerns about the influence of the Bolshevik revolution in the Eastern Question can be noticed through letters, reports and political demonstrations by British diplomats, military and politician (GUPTA, 2017).

In a letter addressed to Churchill in 18 August 1920, Field Marshal Sir Henry Wilson, the Chief of the Imperial General Staff, warned that "In view of the dispersion of our forces, in view of the dangerous weakness to which we are reduced in all theaters" it is possible that there are a number of revolutionary attempts in Ireland, Egypt, Mesopotamia, India and other theaters. (WILSON apud ULLMAN 2019). In 1920's fall, British Major Bray, an intelligence officer linked to the Political Department at the India Office, wrote three reports on the causes of unrest in Mesopotamia with information collected by British intelligence. His conclusion was that revolts were inflated from Berlin and Moscow and that the Soviets in particular, saw advantages to be gained from the spread of the revolution in the Middle East. (MACFIE, 1999).

Curzon and Milner, those primarily responsible for the administration of Mesopotamia, were directly opposed to the proposition to decrease British troops in Georgia and Persia, arguing that this would be equivalent "to an invitation to the Bolsheviks to enter and make themselves master of North Persia (...) would be an end to the Anglo-Persian Agreement which had been concluded with the object of establishing decent conditions and providing a barrier against Bolshevism" (CURZON apud ULLMAN, 2019 p. 365). They also warned that the end of the 
Agreement, which served as a model for the administrations of Egypt and Mesopotamia, would disappear with time, allowing the Bolsheviks to penetrate the borders of Mesopotamia and Persia. It can be said that they clearly described what was conventionally called the domino effect.

The geopolitical rivalry that opposed the British and Tsarist empires was resized by ideological confrontation. In order to unite all anti-imperialist forces, the Comintern established that new tactics of action were needed. This new moment is well portrayed by Zinoviev's declaration at the First Congress of the Peoples of the East held in Baku in September 1920, which even called for a "holy war against British imperialism". Congress drew the attention of the British Cabinet, which published a document in December 1920, warning of the fact that the Soviet regime had as one of its main objectives, "the world revolution" at any cost. (YENEN, 2015)

In a telegram addressed to the Minister of Foreign Affairs of Russia, Kamenev was betting on the revolutionary potential of the revolts in Iraq to the extent that it could spread throughout the region:

\footnotetext{
The insurrections in Mesopotamia have brought to the front the entire policy of the British Government in Central Asia. The British troops in Persia are operating from Bagdad. The evacuation of Mesopotamia which is being sought in some political circles [in England] must entail the evacuation of Persia; on the other hand, pressure on the British troops in North Persia will strengthen the position of the Mesopotamian insurgents. Britain has no troops to send to Mesopotamia except those which are in India and which she is afraid to move. A revolution along the line Enzeli-Hamadan-Bagdad threatens the most vital interests of the British Empire and breaks the status quo in Asia created by the Treaty of Versailles. (KAMENEV apud ULLMAN, 2019, p.374).
}

Although sometimes exaggerated, the perception of the Bolshevik threat on the part of the colonial government had its raison d'être. The Red Army, assisting local forces, took just one month, February 17 to March 17, 1921, to successfully establish a communist government in Georgia. This military campaign coincided with a successful diplomatic action that resulted, in the same month, in the conclusion of agreements for the beginning of "normalization" of the relations between the Soviet government and the three nationalist regimes that came to power in the territories on the south flank from Russia: Turkey, Afghanistan and Persia. Countries that the British Empire had long considered strategically vital to its domination (GÖKAY, 1997).

Russia, whose expansionism had always been regarded by the British as the main threat to India, remained a matter of concern. However, from 1917 onwards the threat seemed to come not so much from the strength of arms, but from the communist ideology that could find fertile soil in the entire region of Asia and the Middle East among the nationalist movements whose growth the war had given impetus to. The editorials of major British newspapers and reports from colonial administrations made alarming predictions about the effects of the combined forces of Bolshevism and nationalism (ULMAN, 2019).

Even though it had no direct influence on the manifestation of Iraqi resistance to the British presence in the 1920 s, it is possible to say that the Bolshevik revolution and its internationalist aspiration represented a threat to British eyes, being one important variable in British equation to sustain its power in Iraq, in that period. 
Conclusion

The Middle East emerged in 1923 completely different from that of 1914. New political movements and ideologies appeared in the emerging debates around the identities and development trajectories of nation-states. A new political class rebelled against the post-war mandate system, while British and French colonial administrators struggled to adapt to the new realities of territorial domination.

The tactics and objectives of colonial rule have changed over time due to political redefinitions and anti-imperialist revolts that have spread across the world. All states under mandate started their existence under some form of military occupation, or indirect rule, whether they were republics like Lebanon and Syria, or monarchies like Iraq and Transjordan. British authorities ensured the pursuit of their interests in access to oil, presence in military installations and communications through a series of unpopular treaties imposed on monarchs and/or parliaments that tried to maintain their statusquo in a delicate balance between submission to imperial powers and maintaining a certain popular support, but always inclined to serve British interests. When Britain left Iraq in 1932, it was clear that British empire felt able to take the risk, because most of the economic and political elite were ahead of Iraq kingdom through British intermediation. That was the main reason, rather than because of a belief that Iraq has reached a condition that allowed it independence.

In this process, it's important to highlight the significant role played by international disputes in the structuring of the State. As political elites operate in their domestic and international environment, their dominance positions are conditioned not only by issues within the national sphere, but fundamentally by the opportunities and challenges arising from the international sphere. The decision by the British to reward the notable Sunnis for their loyalty to positions of dominance in the new Iraqi state and to maintain the privileges of landowners, enabled them to build a lasting alliance with the conservative social forces that would dominate Iraqi politics until the Iraqi revolution in 1958.

There are several academic works that approach historical processes exclusively within national perspectives, forgetting the transnational connections between the countless revolts, revolutions and reactions. There are few attempts to insert them within a single field of perspective, framing them as parts of the same global historical moment: a broadly inherent international anti-colonial nationalist revolution.

References

AMERICAN PEACE SOCIETY. The Mosul Question. Advocate Of Peace Through Justice, New York, v. 87, n. 9, p. 526-528, 1925.

ANGHIE, A. The Evolution of International Law: Colonial and Postcolonial Realities in FALK. In: R.; RAJAOPAL, B.; STEVENS, J. International law and the third world: Reshaping justice. London:Routledge-Cavendish. 2008, chap. 4.

ANGHIE. A. Imperialism, Sovereignty and the Making of International Law. Cambridge: Cambridge University Press, 2004.

BARR, J. A Line in the Sand: Britain, France and the struggle that shaped the Middle East. London: Simon \& Schuster, 2011. 
BRITANNICA, The Editors of Encyclopaedia. William Knox D’Arcy. Encyclopedia Britannica, 7 Oct. 2020a, available in: https://www.britannica.com/biography/William-Knox-DArcy. Accessed 9 February 2021.

BRITANNICA. The Editors of Encyclopaedia. Hashemite. Encyclopedia Britannica, 10 Jan. 2020b, available in: https://www.britannica.com/topic/Hashimite. Accessed 9 February 2021.

CLEVElAnD, W.; BUNTON, M.A History of the Modern Middle East. Boulder, CO: Westview Press. 2009.

CROZIER, A. J. The Establishment of the Mandates System 1919-25: Some Problems Created by the Paris Peace Conference. Journal of Contemporary History,Essex, v. 14, i. 3, p. 483-513, 1979.

DAVIS, R. Britain's Middle Eastern policy, 1900-1931: dual attractions of empire and Europe. Histoire@Politique. Paris, v. 2, i. 11, p. 7, 2010.

DODGE, T. Inventing Iraq: The Failure of Nation-Building and a History Denied. New York: Columbia University Press, 2003.

EHSANI, K. The social history of labor in the Iranian oil industry: the built environment and the making of the industrial working class (1908-1941). Leiden, 2014. p.439. Thesis (PHD) - Royal Netherlands Academy of Arts and Sciences (KNAW) International Institute of Social History (IISG), Leiden University.

ENGDAHL, F. W. A Century of War: Anglo-American Oil Politics and the New World Order. London: Pluto Press, 2004.

FROMKIN, D. A Peace to End All Peace: The Fall of the Ottoman Empire and The Creation of the Modern Middle East. New York: Henry Holt and Co. 2009

GELVIN. J. L. The Modern Middle East. New York: Oxford University Press, 2011

GÖKAY, B. A Clash of Empires Turkey between Russian Bolshevism and British Imperialism, 1918-1923. London; New York: Tauris Academic Studies, 1997.

GROVOGUI, S. N'Z. Sovereigns, quasi sovereigns, and Africans: race and selfdetermination in international law. Minnesota: University of Minnesota Press, 1996.

GUPTA, S. Communism and the Crisis of the Colonial System. In: PONS, S.; SMITH S. The Cambridge History of Communism. Cambridge: Cambridge University Press. 2017, pp. 212 231.

JOUNETT, E. T. A short Introduction to International Law. Cambridge: Cambridge University Press, 2014.

KADHIM, A. Reclaiming Iraq: The 1920 Revolution and the founding of the Modern State. Austin, TX: University of Texas Press, 2012.

KENT, M. Great Britain and the End of the Ottoman Empire, 1900-23. in: KENT, M. The Great Powers and the End of the Ottoman Empire. London: Frank Cass \& Co, 1996. p. 165-198.

KENT, M. Oil and Empire: British Policy and Mesopotamian Oil 1900-1920. London;Basingstoke: Palgrave Macmillan, 1976.

LLEWELLYN-JONES, R. The British Raj and the British Mandate in Iraq. Asian Affairs, London, v. XLVI, i. II, p. 270-279, 2015.

MACFIE, A. L. British Intelligence and the Causes of Unrest in Mesopotamia, 1919-21. Middle Eastern Studies. London, v. 35, i.1, p. 165-177, 1999.

MANELA, E. The Wilsonian Moment: self-determination and the international origins of anticolonial nationalism. Oxford: Oxford University Press, 2007

MARR, P.; AL-MARASHI, I. The Modern History of Iraq. Fourth edition. London; New York: Routledge, 2017.

MCNABB, D. E. Oil and the creation of Iraq: policy failures and the 1914-1918 war in Mesopotamia. New York; London: Routledge: Taylor \& Francis Group, 2016.

MEJCHER, H. Oil and British policy towards Mesopotamia, 1914-1918. Middle Eastern Studies. London, v. 8, i. 3, p. 377-391, 1972.

MILLMAN, B. Pessimism and British War Policy, 1916-1918. $1^{\text {st }}$ Edition. London; New York: Routledge, 2014.

MOSLEY, L. Lord Curzon. Encyclopedia Britannica, 7 Jan. 2021, available in: https://www. britannica.com/biography/Lord-Curzon. Accessed 9 February 2021. 
PEDERSEN, S. The meaning of the mandates system: An argument (League of Nations). Geschichte und Gesellschaft (Vandenhoeck\&Ruprecht). Göttingen, v. 32, i. 4, p. 560-582, 2006.

POOL, D. From Elite to Class: The Transformation of Iraqi Leadership 1920-1939.International Journal of Middle East Studies. Cambridge, v. 12, p. 331-350, 1980.

PURSLEY, S. Lines Drawn on an Empty Map: Iraq's borders and the legend of the artificial state (part 1). Jadaliyya. Washington Dc, USA; Beirut, Lebanon, 2 jun. 2015. Available in https://www. jadaliyya.com/Details/32140/\%60Lines-Drawn-on-an-Empty-Map\%60-Iraq\%E2\%80\%99s-Borders-and-the-Legend-of-the-Artificial-State-Part-1. Access 04 Sept. 2020

RENTON, J. The post-colonial caliphate: Islamic State and the memory of Sykes-Picot. The Convesation. Boston, USA. February 23, 2016. Available in https://theconversation.com/thepost-colonial-caliphate-islamic-state-and-the-memory-of-sykes-picot-52655. Access 27 Aug 2020.

ROGAN, E. The Fall of The Ottomans: The great War on the Middle East. New York: Basic Books, 2015.

SCHAYEGH, C; ARSAN, A. (eds.) The Routledge handbook of the history of the Middle East Mandates, London: Routledge, 2015.

SILVERFARB, D. Britain's Informal Empire in the Middle East: A case Study of Iraq 19291941. New York; Oxford: Oxford University Press, 1982.

SKOCPOL, T. States and Social Revolutions: A comparative analysis of France, Russia and China. Cambridge: Cambridge University Press. 1979.

SLADE, E.; FISCHER, L.; MOHR, A. Oil Imperialism: The International Struggle for Petroleum and The Oil War. Journal of the Royal Institute of International Affairs, Vol. 7, No. 2 (Mar., 1928), pp. 148-149.

SLUGLETT, P. Britain in Iraq: Contriving King and Country. London: New York: I.B. Tauris, 2007.

TREATY OF VERSAILLES. Treaty and protocol signed at Versailles June 28, 1919. p.43-240. Available in: <https://www.loc.gov/law/help/us-treaties/bevans/m-ust000002-0043.pdf> access 09/02/2021.

TRIPP, C. A History of Iraq. Thirdedition. Cambridge: Cambridge University Press, 2008.

ULLMAN, James R. Anglo-Soviet Relations, 1917-1921, Volume 3: The Anglo-Soviet Accord. Princeton: Princeton University Press, 2019.

ULRICHSEN, K. C. The First World War in the Middle East. London: Oxford University Press, 2014

YAVUZ, R. Effects of the Decisions of San Remo Conference on Syria and Iraq.Tarih İncelemeleri Dergisi. Izmir, Turkey, v. XXXII, i.2, p. 565-600, 2017.

YENEN, A. The Other Jihad: Enver Pasha, Bolsheviks, and Politics of Anticolonial Muslim Nationalism during the Baku Congress 1920. In: FRASER, G. T. The First World War and its Aftermath: The Shaping of the Middle East.London: Gingko Library, 2015. 